Journal of Epidemiology and Public Health (2018), 3(3): 342-352

https://doi.org/10.26911/jepublichealth.2018.03.03.05

\title{
Analysis of the Contextual Effect of Village Characteristics and Other Determinants of Diarrhea in Children Under Five, Banjarnegara, Central Java
}

\author{
Lusia Arina Cahyaningrum(1)3), Setyo Sri Rahardjo 2), Bhisma Murti1) \\ ${ }^{1)}$ Masters Program in Public Health, Universitas Sebelas Maret \\ ${ }^{2)}$ Faculty of Medicine, Universitas Sebelas Maret \\ 3)District Health Office Banjarnegara, Central Java
}

\begin{abstract}
Background: Diarrheal disease is the leading cause of child death and illness in the world. Diarrhea is one of the most potent endemic diseases in Indonesia. Children under five were the most affected group by this disease. This study aimed to determine the effect of nutritional status, information exposure, prevention behavior, income, social capital, and environmental sanitation on the incidence of diarrhea in children under five in Banjarnegara District, Central Java, using multilevel analysis.

Subjects and Method: This was an analytic observational study with a case-control design. The study was conducted in Banjarnegara, Central Java, from January to February 2018. A total of 25 villages was selected using stratified random sampling, based on village stratification criteria. A sample of 250 children under five was selected for this study by fixed disease sampling, consisting of 125 children with diarrhea and 125 healthy children. The dependent variable was diarrhea. The independent variables at level 1 were nutritional status, information exposure, prevention behavior, income, social capital, and environmental sanitation. Village stratification was used as the contextual factor at level 2. The data were collected by a set of pre-tested questionnaire and analyzed by multilevel logistic regression analysis using Stata 13 .

Results: Poor nutritional status $(b=1.33 ; 95 \% \mathrm{CI}=-0.14$ to $2.82 ; \mathrm{p}=0.077$ ), poor prevention behavior $(b=1.52 ; 95 \% \mathrm{CI}=0.81$ to $2.24 ; \mathrm{p}<0.001)$, low income $(\mathrm{b}=1.52 ; 95 \% \mathrm{CI}=0.80$ to 2.25 ; $\mathrm{p}<0.001)$, weak social capital $(\mathrm{b}=1.80 ; 95 \% \mathrm{CI}=1.04$ to $2.56 ; \mathrm{p}<0.001)$, and poor environmental sanitation $(b=1.12 ; 95 \% \mathrm{CI}=0.39$ to $1.85 ; \mathrm{p}=0.003)$ increased the risk of diarrhea. Exposure to information $(b=0.90 ; 95 \% \mathrm{CI}=0.17$ to $1.64 ; \mathrm{p}=0.015)$ decreased the risk of diarrhea. The village stratification showed a strong contextual effect on the incidence of diarrhea with intra-class correlation $(\mathrm{ICC})=15.78 \%$.
\end{abstract}

Conclusion: Poor nutritional status, poor personal hygiene, low income, weak social capital, and poor environmental sanitation increase the risk of diarrhea.

Keywords: determinant, diarrhea, children under five, multilevel analysis

Correspondence:

Lusia Arina Cahyaningrum. Masters Program in Public Health, Universitas Sebelas Maret, Jl. Ir. Sutami 36 A, Surakarta, Indonesia. Email: lusiaarina@gmail.com.

Mobile: +6282226835687 .

\section{BACKGROUND}

Diarrheal disease is the leading cause of children death and illness in the world, and is largely due to contaminated food and water sources. Worldwide, 780 millions people lack access to good drinking water and 2.5 billions do not have good sani- tation. Infectious diarrhea is widespread throughout developing countries (WHO / UNICEF, 2017).

In total, an estimated of $58 \%$ (34$72 \%)$ of all diarrheal cases occur in lowand middle-income countries, or $57 \%$ worldwide, due to the environment, result- 
ing in 842,000 deaths annually (PrüssUstün et al ., 2012). Children under the age of three experience an average of three episodes of diarrhea each year in lowincome countries. Each episode removes the nutrients needed for growth. As a result, diarrhea is a major cause of malnutrition, whereas malnourished children are more likely to experience diarrhea (WHO / UNICEF, 2017).

Diarrhea is still one of the most potent endemic diseases in Indonesia and often leads to death. Based on infectious diseases, diarrhea is the third leading cause of death after TB and Pneumonia (Ministry of Health, 2011b).

The incidence of diarrhea based on symptoms in all age groups was $3.5 \%$ and incidence of diarrhea in children under five was $6.7 \%$. The period prevalence of diarrhea of all age groups was $7 \%$ and in children under five was $10.2 \%$. The group of diarrhea sufferers is mostly in the age group of children under five (Ministry of Health, 2013).

Based on the Health Profile of Indonesia, in 2015, there were outbreaks of diarrhea spread in 11 provinces, 18 districts / cities, with the number of 1,213 people with 30 deaths and $2,47 \%$ case fatality rate (CFR). The mortality rate when outbreak of diarrhea is expected to be $<1 \%$.

Environmental-based health challenges caused by the use of clean water, inadequate sanitation, and poor hygiene behavior can cause the incidence of diarrheal diseases (Lawrence et al., 2016).

The contribution of individual factors that affect the incidence of diarrhea also varies in different regions or regions, among others, due to cultural differences and social values, economic status, gender, maternal education as caretakers, knowledge of hygienic behavior as well as eating habits and hygiene behavior to prevent diarrhea (Ma et al., 2014; Pang et al., 2015; Budhathoki et al., 2016)

The incidence of the disease is closely linked to a risk factor that is basically all of the factors that play locally specific in each disease event. One strategy which is in line with the concept is the Desa Siaga program which is expected to be able to independently identify the risk factors, overcome health problems and be able to apply clean and healthy living behavior (PHBS) (Ministry of Health RI 2010).

The proportion of cases of diarrhea in Central Java, in 2015 was about 67.7 percent. The clinical prevalence of diarrhea in Central Java was $4.7 \%$, the rate is greater than the prevalence of clinical diarrhea in Indonesia of $3.5 \%$ (Dinkesprop Jateng, 2017).

The estimated number of people with diarrhea in Banjarnegara Regency is 21,702 people from 1,041,104 population of Banjarnegara. Meanwhile, the number of diarrhea sufferers reported was handled at the health facility was 22,306 people (101, $5 \%$ ). The percentage of population with decent sanitation access (healthy latrines) is still quite low at $45.1 \%$. The number of villages that have implemented the behavior of stop defecating arbitrarily ranged $18.35 \%$ or 18 villages of the total 278 villages and sub-districts (Health office of Banjarnegara, 2017).

The purpose of this study was to analyze the incidence of diarrhea in infants in Banjarnegara regency based on PRECEDEPROCEED model using multilevel analysis.

\section{Study design}

The study is an observational analytic study with cross sectional design. It was conducted in Banjarnegara, Central Java, Indonesia, from January to February 2018. 
Journal of Epidemiology and Public Health (2018), 3(3): 342-352

https://doi.org/10.26911/jepublichealth.2018.03.03.05

\section{Population and sample}

The source population in this study was toddlers in Banjarnegara regency. The sampling used was fixed disease sampling technique. The subjects consisted of 250 people, coming from 10 subjects in each unit level 2 i.e. 25 villages.

\section{Study variables}

The dependent variable was diarrhea. The independent variables were nutritional status, information exposure, diarrhea prevention behavior, family income, social capital, environmental sanitation.

\section{Operational definition of variable}

The occurrence of diarrhea is described as a condition in which there is defecation with consistency of fluid with mucus / not, blood / not with frequency of $3 x$ a day in the last 2 months.

The nutritional status of children under five years of age was measured by an antopometric measurement based on body weight by age (WAZ).

Exposure of information was defined as information received by mothers through various media or activity about behavior of prevention and the diarrhea disease.

Diarrhea prevention behavior was defined as a behavior shown by respondents in preventing the occurrence of diarrheal disease.

Family income was defined as a state that describes the income of the whole family obtained through working done with the average income per month in the last 6 months.

Social capital represents a mutual movement among people in a society and social organization to achieve the goal of living together that cannot be achieved personally.

Environmental sanitation was defined as the environmental conditions surrounding the houses where the respondent resides are related to the ownership of healthy latrines, the availability of clean water, the disposal of waste water and the garbage disposal facilities.

Strata desa siaga was defined as a strata of the village where the residents easily get daily health services, able to develop UKBM, carry out communitybased surveillance and environmental sanitation so that people apply Clean and Healthy Behavior.

\section{Study instrument}

The assessment of nutritional status was done by weight measurement using scales, then it is assessed based on the anthropometric standard of child nutritional status assessment which has been determined by Ministry of Health. The environmental sanitation data uses an observation sheet. Data on standby village stratum were obtained based on the annual report of District Health Office. Other data were obtained using questionnaires.

\section{Data Analysis}

Univariate analysis was conducted to see the frequency distribution and percentage characteristics of the subjects. Bivariate analysis was conducted to study the relationship between diarrhea occurrence and the independent variables using chi-square test and odds ratio calculation (OR) with confidence level (CI) of 95\%. Furthermore, multivariate analysis was conducted by a multilevel logistic regression.

\section{Research Ethics}

The research ethics included informed consent, anonymity, confidentiality and ethical clearance. The ethical clearance in this study was conducted in Dr. Moewardi hospital, Surakarta, Central Java.

\section{RESULTS}

\section{Subjects characteristics}

The subjects consisted of 250 children. Case group (diarrhea) of 125 under five 
children and 125 under-five children in control group (not diarrhea). The frequency distribution of the characteristics of the study subjects is described in Table 1 .

Table 1 shows that the proportion of maternal age in children experienced the highest incidence of diarrhea in the age group $\geq 30$ years for about 63 people (49.2\%), as well as the proportion of maternal age whose children did not experience the highest diarrhea incidence in the age group $\geq 30$ years for about 65 people 50.8\%).

Most of the mothers did not work, both in children without diarrhea for about 84 people (46.9\%) and toddlers who expe- rienced diarrhea of 95 people (53.1\%). Most of the education level of mothers whose children did not experience diarrhea was high school graduate with 37 people (67.3\%).

\section{Bivariate analysis on the deter- minants of diarrhea}

Bivariate analysis was conducted to observe the existence of independent variables (nutritional status, information exposure, prevention behavior, income, social capital, and environmental sanitation) with the dependent variable (diarrhea occurrence). The result of bivariate analysis can be seen in table 2.

\section{Table 1. The Characteristics of Subjects}

\begin{tabular}{|c|c|c|c|c|c|c|}
\hline \multirow{3}{*}{$\begin{array}{c}\text { Subject } \\
\text { Characteristics }\end{array}$} & \multicolumn{4}{|c|}{ Diarrhea Occurrence } & \multirow{2}{*}{\multicolumn{2}{|c|}{ Total }} \\
\hline & \multicolumn{2}{|c|}{ No diarrhea } & \multicolumn{2}{|c|}{ diarrhea } & & \\
\hline & $\mathbf{n}=\mathbf{1 2 5}$ & $\%$ & $\mathbf{n}=\mathbf{1 2 5}$ & $\%$ & $\mathbf{n}=\mathbf{2 5 0}$ & $\%$ \\
\hline \multicolumn{7}{|l|}{ Maternal Age } \\
\hline$<30$ years old & 60 & 49.2 & 62 & 50.8 & 122 & 100 \\
\hline$\geq 30$ years old & 65 & 50.8 & 63 & 49.2 & 128 & 100 \\
\hline \multicolumn{7}{|l|}{ Maternal Occupation } \\
\hline Not working & 84 & 46.9 & 95 & 53.1 & 179 & 100 \\
\hline Labor & 3 & 33.3 & 6 & 66.7 & 9 & 100 \\
\hline Employee & 19 & 61.3 & 12 & 38.7 & 31 & 100 \\
\hline Entrepreneur & 13 & 72.2 & 5 & 27.8 & 18 & 100 \\
\hline Civil Servant & 6 & 46.2 & 7 & 53.8 & 13 & 100 \\
\hline \multicolumn{7}{|l|}{ Maternal Education } \\
\hline No formal education & 4 & 57.1 & 3 & 42.9 & 7 & 100 \\
\hline Primary school & 25 & 32.9 & 51 & 67.1 & 76 & 100 \\
\hline Junior high school & 37 & 46.3 & 43 & 53.8 & 80 & 100 \\
\hline Senior high school & 37 & 67.3 & 18 & 32.7 & 55 & 100 \\
\hline University & 22 & 68.8 & 10 & 31.3 & 32 & 100 \\
\hline \multicolumn{7}{|l|}{ Strata of desa siaga } \\
\hline Pratama & 20 & $33 \cdot 3$ & 40 & 66.7 & 60 & 100 \\
\hline Madya & 30 & 42.9 & 40 & 57.1 & 70 & 100 \\
\hline Purnama & 26 & 43.3 & 34 & 56.7 & 60 & 100 \\
\hline Mandiri & 49 & 81.7 & 11 & 18.3 & 60 & 100 \\
\hline
\end{tabular}

\section{The results of multilevel analysis}

Multivariate analysis describes the effects independent variables to a dependent variable by a multilevel logistic regression. Table 3 showed that abnormal nutritional status $(b=1.33 ; 95 \% \mathrm{CI}=-0.14$ to $2.82 ; \mathrm{p}=$ $0.077)$, lack of information exposure $(b=$ $0.90 ; 95 \% \mathrm{CI}=0.17$ to $1.64 ; \mathrm{p}=0.015)$, poor prevention behavior $(\mathrm{b}=1.52 ; 95 \% \mathrm{CI}=0.81$ to $2.24 ; \mathrm{p}<0.001$ ), income $<\mathrm{Rp} 1,490,000$ $(b=1.52 ; 95 \% \mathrm{CI}=0.80$ to $2.25 ; \mathrm{p}<0.001)$, weak social capital $(b=1.80 ; 95 \% \mathrm{CI}=1.04$ to 2.56 ; $\mathrm{p}<0.001$ ), and poor environmental sanitation $(b=1.12 ; 95 \% \mathrm{CI}=0.39$ to 1.85 ; $\mathrm{p}=0.003$ ) were positively associated with diarrhea in children. 
Journal of Epidemiology and Public Health (2018), 3(3): 342-352

https://doi.org/10.26911/jepublichealth.2018.03.03.05

Table 2. Bivariate Analysis of Determinants of Diarrhea Occurrence

\begin{tabular}{|c|c|c|c|c|c|c|c|c|c|}
\hline \multirow{3}{*}{ Variable } & \multicolumn{4}{|c|}{ Diarrhea Occurrence } & \multirow{2}{*}{\multicolumn{2}{|c|}{ Total }} & \multirow{3}{*}{$\mathbf{O R}$} & \multirow{3}{*}{$95 \% \mathrm{CI}$} & \multirow{3}{*}{$\mathbf{p}$} \\
\hline & \multicolumn{2}{|c|}{ No diarrhea } & \multicolumn{2}{|c|}{ diarrhea } & & & & & \\
\hline & $\mathbf{n}$ & $\%$ & $\mathbf{n}$ & $\%$ & $\mathbf{n}$ & $\%$ & & & \\
\hline \multicolumn{10}{|c|}{ Nutritional status } \\
\hline Normal & 119 & 51.5 & 112 & 48.5 & 231 & 100 & \multirow[t]{2}{*}{2.3} & \multirow{2}{*}{$0.8-6.3$} & \multirow[t]{2}{*}{0.095} \\
\hline Underweight & 6 & 31.6 & 13 & 68.4 & 19 & 100 & & & \\
\hline \multicolumn{10}{|l|}{$\begin{array}{l}\text { Information } \\
\text { exposure }\end{array}$} \\
\hline Good & 81 & 68.6 & 37 & 31.4 & 118 & 100 & \multirow[t]{2}{*}{4.4} & \multirow[t]{2}{*}{$2.6-7.4$} & \multirow[t]{2}{*}{$<0.001$} \\
\hline Poor & 44 & 33.3 & 88 & 66.7 & 132 & 100 & & & \\
\hline \multicolumn{10}{|l|}{$\begin{array}{l}\text { Prevention } \\
\text { behavior }\end{array}$} \\
\hline Good & 98 & 71 & 40 & 29 & 138 & 100 & \multirow[t]{2}{*}{$7 \cdot 7$} & \multirow[t]{2}{*}{$4.4-13.6$} & \multirow[t]{2}{*}{$<0.001$} \\
\hline Poor & 27 & 24.1 & 85 & 75.9 & 112 & 100 & & & \\
\hline \multicolumn{10}{|l|}{ Family income } \\
\hline High & 96 & 67.6 & 46 & 32.4 & 142 & 100 & \multirow[t]{2}{*}{$5 \cdot 7$} & \multirow{3}{*}{$3.3-9.9$} & \multirow{2}{*}{$<0.001$} \\
\hline Low & 29 & 26.9 & 79 & 73.1 & 108 & 100 & & & \\
\hline \multicolumn{9}{|l|}{ Sosial capital } & \\
\hline Strong & 70 & 72.2 & 27 & 27.8 & 97 & 100 & \multirow[t]{2}{*}{4.6} & \multirow[t]{2}{*}{$2.7-8.0$} & \multirow[t]{2}{*}{$<0.001$} \\
\hline Weak & 55 & $35 \cdot 9$ & 98 & 64.1 & 153 & 100 & & & \\
\hline \multicolumn{10}{|l|}{$\begin{array}{l}\text { Environmental } \\
\text { sanitation }\end{array}$} \\
\hline Good & 78 & 60 & 52 & 40 & 130 & 100 & 2.3 & $1.4-3.9$ & 0.001 \\
\hline Poor & 47 & 39.2 & 73 & 60.8 & 120 & 100 & & & \\
\hline
\end{tabular}

Table 3 The results of a multilevel logistic regression on the determinants of diarrhea occurrence in children

\begin{tabular}{lcccc}
\multicolumn{1}{c}{ Diarrhea } & \multirow{2}{*}{ OR } & \multicolumn{2}{c}{$\mathbf{9 5 \%}$ CI } & \multirow{2}{*}{ p } \\
Fixed Effect & & Lower & upper & \\
Abnormal nutritional status & 1.33 & -0.14 & 2.82 & 0.077 \\
Lack of information exposure & 0.90 & 0.17 & 1.64 & 0.015 \\
Poor prevention behavior & 1.52 & 0.81 & 2.24 & $<0.001$ \\
Income <Rp 1,490,000 & 1.52 & 0.80 & 2.25 & $<0.001$ \\
Lack of social capital & 1.80 & 1.04 & 2.56 & $<0.001$ \\
Poor environment sanitation & 1.12 & 0.39 & 1.85 & 0.003 \\
Random Effect & & & & \\
Strata of desa siaga & 0.61 & 0.10 & 3.48 & \\
n observasi = 250 & & & & \\
Log likelihood = - 105.1 & & & & \\
LR test vs. logistic regression, p< 0.001 & & & & \\
ICC = 15.78\% & & & & \\
\hline
\end{tabular}

In the multilevel analysis, the ICC = 15.78\%. The indicator indicated that the condition of standby village in each strata has a contextual influence on the occurrence of diarrhea by $15.78 \%$. The number was larger than the standard of role of thumb size of $8-10 \%$. It showed that village stratification had a strong contextual effect on the incidence of diarrhea.

\section{DISCUSSIONS}

1. The effect of nutritional status on the incidence of diarrhea.

The result of this study showed that there was a significant effect between children's nutritional status and the incidence of diarrhea. Children with poor nutritional status increased the risk of diarrhea. In this study, as many as 112 children (48.5\%) 
from 231 children with normal nutrition have diarrhea. This was probably because there were several other factors beside the nutritional status that caused the toddlers to experience diarrhea. Some causes of diarrhea in addition to bacterial or viral infections, among others, were allergies, mal absorption, poisoning, immune deficiency, and other causes (Soebagyo, 2008; Widoyono, 2011; Irianto, 2014).

A study by Narzah (2016) about factors related to the incidence of diarrhea in Purbalingga District stated that nutritional status has a direct influence on the incidence of diarrhea.

Tickell et al. (2017) compared the severity of diarrheal disease that occurred in children with and without malnutrition. Children with malnutrition experienced more severe diarrhea than children who were not malnourished. The malnutrition status of toddlers suffering from diarrhea was more accompanied by the prevalence of pathogens in feces. The prevalence of pathogens reduces immune response and increased the risk of diarrhea.

According to WHO/UNICEF (2017), severe diarrhea caused loss of fluid, and may be life-threatening, especially in young children and people who were malnourished or have impaired immunity.

Children with severe malnutrition have an increased risk of acute infectious diseases and death (Bhutta et al., 2017). Malnourished children have a higher likelihood of having persistent diarrhea, and thin children have a higher risk of having diarrheal episodes that progressed to persistent diarrhea (Budhathoki et al., 2016).

\section{The effect of health information exposure on the incidence of diarrhea.}

The result of this study showed that there was an effect between health information exosure and the incidence of diarrhea. Mothers with poor exposure information may increase the risk of diarrhea in children.

Diouf et al. (2014) explained that the prevalence of diarrhea was found to be lower in children where the primary caregiver/ nanny has received access to information about health education $(\mathrm{OR}=0.45$; 95\% CI= 0.21 to $0.97 ; \mathrm{p}=0.043)$. Health information especially about handwashing with soap in Burundi effectively prevented and protected children from diarrheal diseases.

Similar to a study by Ejemot-Nwadiaro et al. (2015) which showed that an average decreased in episodes of diarrhea was 1.68 times less in the intervention groups, which were groups that received health information about handwashing practices in risk populations at home. The provision of health information also affected the frequency of hand washing by seven times per day compared to the control group by three times per day.

The information about the way for a healthy life, health care, avoiding illness and others would increase the knowledge of individuals, groups or communities. The enhancement of knowledge was expected to improve the understanding and could change the behavior to be healthier (Sulaeman et al., 2015)

\section{The effect of diarrhea prevention behaviour on the incidence of diarrhea.}

The result of this study showed that there was an effect between diarrhea prevention behavior and the incidence of diarrhea. Mothers with poor prevention behavior increased the risk of diarrhea in children.

The results of this study is consistent with a study by Agustina et al. (2013), which stated that maternal hygiene behavior in preparing and managing food in 
young children. Budhathoki et al., (2016) stated that the practice of washing hands with soap and flowing water had a preventive effect on the incidence of diarrhea. Proper handwashing practices could reduce more than one-third of the diarrhea episodes (Beaugerie and Sokol, 2013; Budhathoki et al., 2016).

Ma et al., (2014) studied that there were 6 behavioral factors which significantly related to the incidence of diarrhea: hand washing before meals and after defecate, hand washing behavior by using soap and flowing water, the consumption of raw seafood behaviour, using the same knife and cutting board for raw or processed food, using the same chopsticks to pick up raw or cooked food, and performing regular physical activity.

One of the things that can prevent diarrhea and pathogen infection was the behaviour of defecation in healthy latrines and did not dispose adults or children's feces in the wrong places (Sevilimedu et al., 2017). In contrast to the study by Islam $e t$ al., (2018) which stated that most households in Bangladesh perform unsafe children's feces disposal practices. This practice was not associated with diarrhea because the child's feces may not be the main exposure to dirt that contributed significantly to the risk of enteric disease occurring in the country.

\section{The effect of family income on the incidence of diarrhea.}

The result of this study showed that there was an effect between family income and the incidence of diarrhea. Children with low family income have a higher risk of diarrhea than toddlers with high family income.

The embodiment of healthy behavior required health facilities and infrastructure such as soap, clean water facilities, the availability of trash can, and others. And all of these things required money (Tarwoto and Wartonah, 2011; Woldu et al., 2016). The prevalence of diarrhea tend to be higher in groups with lower household expenses per capita (Ministry of Health RI, 2011).

The result of this study is consistant with a study by Azage et al., (2016) which showed that the probability of diarrhea occurring in children from poor households was 1.63 times $(\mathrm{OR}=1.63 ; 95 \% \mathrm{CI}=1.12$ to 2.36) higher than children from wealthy households. People from wealthy households tend to apply better hygienic and environmental sanitation behaviors and become their standard of living, therefore, it can prevent the incidence of diarrhea.

\section{The effect of social capital on the incidence of diarrhea.}

The result of this study showed that there was an effect between social capital and the incidence of diarrhea. Toddlers in an environment with weak social capital increased the risk of experiencing diarrhea. According to Hasbullah (2006) in Susilo, (2016), the core dimension of social capital placed in people's ability to work together to build a network to achieve common goals. This was reinforced by the values and norms that became the main elements such as trust, reciprocity, caring, giving, and receiving.

Strong social capital enabled the community members to share health information, access, and better use of resources which were available in the community for local problem solving in order to improve community health status (Murti, 2010; Bisung et al., 2014).

Social capital was associated with the ability to identify health problems through the exchange of information such as neighbors advising each other and providing advice or information to obtain health services (Sutisna et al., 2006). 
A study by Levison et al., (2011) in the village of Usoma, Kenya revealed that the lack of trust among the community was a major obstacle to overcome water and sanitation problems in that area. Access to water and sanitation would reduce waterborne diseases, especially diarrhea in children (Kamara et al., 2017).

Regardless of the difference in social status, societies with higher levels of social capital, especially in terms of social and network participation, showed healthier behavior and feel healthier both physically and psychologically (Nieminen et al., 2013).

\section{The effect of environmental sanita- tion on the incidence of diarrhea}

This study also produced findings that there was an effect of environmental sanitation on the incidence of diarrhea. Children with poor environmental sanitation were at risk for experiencing diarrhea compared to toddlers who have good environmental sanitation. Ministry of Health RI, (2017) stated that sanitation that did not fulfill health requirements lead to the emergence of environmental-based diseases, one of them was diarrhea.

Environmental sanitation factors in a research conducted in Ethiopia on 600 subjects, including the availability of toilet facilities, solid waste disposal methods, and household drinking water were significant risk factors causing diarrhea in children. Children from the households which did not have toilet facilities were 2 times more likely to have diarrhea than those from households with better toilet conditions (Asfaha et al., 2018).

The result of a study by Tauso and Azizah (2013), showed that the most dominant factor in the incidence of diarrhea was family's toilet. If there was no toilet, adults and children should defecate away from homes, streets, water sources, or children's playgrounds. Furthermore, the feces were dumped with soil. In people who did not have toilets should be considered to build the toilet together. However, every household should have a toilet (UNICEF, 2010). This was supported by a study done by Bitew et al. (2017) reported that the existence of inadequate and unprotected water resources was significantly one of the predictors of diarrhea in children.

\section{The effect of village stratification} on the incidence of diarrhea

The results showed that the condition of standby village in each strata has a contextual influence on the occurrence of diarrhea by $15.78 \%$, so it was highly important to note.

Allert village was one of the strategies that has the leverage to move and empower the community as a step to healthy village. Standby village was expected to solve health problems, disaster, and health emergency independently. The main purpose of standby village was to empower the community. Empowerment as a facilitation effort that was persuasive and non-instructive through an organized learning process to foster a well-coordinated response (Hill et al., 2014).

The mutual cooperation activities as a form of active participation of the community in relation to environmental sanitation in active standby village which can be developed, among others, environmental improvement movement in the form of clean water facilities development, clean Friday activity, sewerage, improvement of healthy houses, and also the movement prevention and control of disease risk factors and health problems (Central Java Provincial Health Office, 2011).

\section{REFERENCES}

Agustina, R. Sari TP, Satroamidjojo S, Bovee-Oudenhoven IMJ, Feskens EJM, Kok FJ (2013). Association of 
food-hygiene practices and diarrhea prevalence among Indonesian young children from low socioeconomic urban areas. BMC Public Health. BMC Public Health, 13(1): 1. doi: 10.1186/1471-2458-13-977.

Asfaha KF, Tesfamichael FA, Fisseha GK, Misgina KH, Weldu MG, Welehaweria NB, Gebregiorgis YS (2018). Determinants of childhood diarrhea in Medebay Zana District, Northwest Tigray, Ethiopia: A community based unmatched case-control study. BMC Pediatrics. BMC Pediatrics, 18(1): 19. doi: 10.1186/s12887-018-1098-7.

Azage M, Kumie A, Worku A, Bagtzoglou AC (2016). Childhood diarrhea in high and low hotspot districts of Amhara Region, northwest Ethiopia: a multilevel modeling. Journal of Health, Population and Nutrition. Journal of Health, Population and Nutrition. 1-14. doi: 10.1186/s41043016-0052-2.

Beaugerie L, Sokol H (2013). Diarrhées infectieuses aiguës de l'adulte : épidémiologie et prise en charge', La Presse Médicale, 42(1): 52-59. doi: 10.1016/j.lpm.2012.09.014.

Bhutta ZA, Berkley JA, Bandsma RHJ, Kerac M, Trehan I, Briend A (2017). Severe childhood malnutrition. Nature Reviews Disease Primers, 3: 17067. doi: 10.1038/nrdp.2017.67.

Bisung E, Elliott SJ, Schuster-Wallace CJ, Karanja DM, Bernard A (2014). Social capital, collective action and access to water in rural Kenya. Social Science and Medicine. Elsevier Ltd, 119: 147154. doi: 10.1016/j.socscimed.2014.07.060.

Bitew BD, Woldu W, Gizaw Z (2017). Childhood diarrheal morbidity and sanitation predictors in a nomadic community. Italian Journal of Pediatrics.
Italian Journal of Pediatrics, 43(1): 18. doi: 10.1186/s13052-017-0412-6.

Budhathoki SS, Bhattachan M, Yadav AK, Upadhyaya P, Pokharel PK (2016). Eco-social and behavioural determinants of diarrhea in under-five children of Nepal: a framework analysis of the existing literature. Tropical Medicine and Health. Tropical Medicine and Health: 1-7. doi: 10.1186/s41182016-0006-9.

Tickell KD, Pavlinac PB, John-Stewart GC, Denno DM, Richardson BA, Naulikha JM, Kirera RK, et al. (2017). Impact of Childhood Nutritional Status on Pathogen Prevalence and Severity of Acute Diarrhea. The American Journal of Tropical Medicine and Hygiene, 97(5): 1337-1344. doi: 10.4269/ajtmh.17-0139.

Dinkes Kab Banjarnegara (2017) Dinkes dalam Angka Tahun 2017. Banjarnegara: DinkesKab Banjarnegara.

Dinkes Provinsi Jateng (2017) Profil 2016. Available at: http://www.dinkesjatengprov.go.id/v2015/dokumen/profil2016/mobile/index.html \#p=1.

(2011) Pedoman penentuan strata desa/kelurahan siaga aktif Provinsi Jawa Tengah. Edited by indiyah widiastuti. Semarang: Dinkesprop Jateng.

Diouf K, Tabatabai P, Rudolph J, Marx M (2014). Diarrhoea prevalence in children under five years of age in rural Burundi: an assessment of social and behavioural factors at the household level. 1-9.

Ejemot-Nwadiaro RI, Ehiri JE, Arikpo D, Meremikwu MM, Critchley JA (2015). Hand washing promotion for preventing diarrhoea. Cochrane Database of Systematic Reviews, 2015(9). doi: 10.1002/14651858.CDo04265.pub3.

Hill PS, Goeman L, Sofiarini R, Djara MM 
(2014). "Desa SIAGA", the "Alert Village": The evolution of an iconic brand in Indonesian public health strategies. Health Policy and Planning, 29(4): 409-420. doi: 10.1093/heapol/czto27.

Irianto (2014). Epidemiologi Penyakit Menular dan tidak menular: panduan Klinis. Bandung: Alfabeta.

Islam M, Ayse E, Sania A, Rahman M, Shoab AK (2018). Unsafe disposal of feces of children $<3$ years among households with latrine access in rural Bangladesh: Association with household characteristics, fly presence and child diarrhea. Plos One. Edited by K. A. Dearden. Public Library of Science, 13(4): e0195218. doi: 10.1371/journal.pone.0195218.

Kamara JK, Galukande M, Maeda F, Luboga S, Renzaho AMN (2017). Understanding the challenges of improving sanitation and hygiene outcomes in a community based intervention: A cross-sectional study in rural Tanzania. International Journal of Environmental Research and Public Health, 14(6): 1-16. doi: 10.3390/ijerph14060602.

Kemenkes RI (2010) Kepmenkes Nomor 1529/Menkes/SK/X/2010 Tentang Pedoman Umum Pengembangan Desa dan Kelurahan Siaga Aktif. (2011a). Panduan Sosialisasi Tatalaksana Diare Pada Balita. Jakarta. (2011b). Situasi diare di Indonesia. Jurnal Buletin jendela data \& informasi kesehatan, 2: 1-44.

(2013) Riset Kesehatan Dasar Indonesia. Edited by Badan Penelitian Dan Pengembangan Kesehatan.Jakarta: kemenkes RI.

(2017) 5 Pilar Kurangi Penyakit Berbasis Lingkungan. Available at: http://www.depkes.go.id/article/view /17032100003/5-pilar-kurangi-penyakit-berbasis-lingkungan.html.

Lawrence JJ, Yeboah-Antwi K, Biemba G, Ram PK, Osbert N, Sabin LL, Hamer DH (2016). Beliefs, Behaviors, and Perceptions of Community-Led Total Sanitation and Their Relation to Improved Sanitation in Rural Zambia. 94(3): 553-562. doi: 10.4269/ajtmh.15-0335.

Levison MM, Elliott SJ, Karanja DM, Schuster-Wallace CJ, Harrington DW (2011). You cannot prevent a disease; you only treat diseases when they occur: knowledge, attitudes and practices to water-health in a rural Kenyan community. East African journal of public health, 8(2): 103-11. Available at: http://www.ncbi.nlm.nih.gov/pubmed/22066295.

Ma C, Wu S, Yang P, Li H, Tang S, Wang Q (2014). Behavioural factors associated with diarrhea among adults over 18 years of age in Beijing, China. 14(1): 1-7. doi: 10.1186/1471-2458-14-451.

Murti B (2010). Determinan sosio-ekonomi, modal sosial, dan implikasinya bagi kesehatan masyarakat. Guru Besar Ilmu Kesehatan Masyarakat. Available at: http://scholar.google.com/scholar?hl=en\&btnG=Search\&q =intitle:Determinan+sosio-ekonomi,+ modal+sosial,+dan+implikasinya $+\mathrm{b}$ agi+kesehatan+masyarakat\# 0 .

Narzah NA (2016). Path Analysis FaktorFaktor Yang Berhubungan Dengan Kejadian Diare Pada Bayi (6 - 12 Bulan) di Wilayah Kerja Puskesmas Karanganyar Kabupaten Purbalingga. Universitas Sebelas Maret.

Nieminen $T$, Prättälä $R$, Martelin $T$, Härkänen T, Hyyppä MT, Alanen E, Koskinen S (2013). Social capital, health behaviours and health: A population-based associational study. 
BMC Public Health, 13(1). doi: 10.1186/1471-2458-13-613.

Pang J, Chua SWJL, Hsu L (2015). Current knowledge, attitude and behaviour of hand and food hygiene in a developed residential community of Singapore: a cross- sectional survey. BMC Public Health. BMC Public Health: 1-12. doi: 10.1186/s12889-015-1910-3.

Prüss-Üstün, Annette, Wolf J, Corvalán, Carlos F, Bos R, Neira, Purificación $M$ (2012). Preventing disease through healthy environments: a global assessment of the burden of disease from environmental risks. http://www.who.int/iris/handle/10665/204585 .

Sevilimedu V, Pressley KD, Snook KR, Hogges JV, Politis MD, Sexton JK, et al. (2017). Gender-based differences in water, sanitation and hygienerelated diarrheal disease and helminthic infections: a systematic review and meta-analysis. Transactions of The Royal Society of Tropical Medicine and Hygiene. doi: 10.1093/trst$\mathrm{mh} /$ trwo8o.

Soebagyo (2008) Diare akut pada anak. I. Surakarta: UNS Press.

Sulaeman ES, Murti B, Waryana (2015). Aplikasi Model Pada Perencanaan Program Pemberdayaan Masyarakat Bidang Kesehatan Berbasis Penilaian Kebutuhan Kesehatan Masyarakat The Application of PRECEDE-PROCEED Model in Community Empowerment Planning in Health Sector Based on the Need Assessment of', Jurnal Kedokteran Yarsi, 23(3): 149164.

Susilo S (2016). Peran Modal sosial dalam pertumbuhan ekonomi Indonesia Tahun 1980-2013. Universitas Sebelas Maret.

Sutisna E, Karsidi R, Murti B, Kartono DT, Waryana W, Hartanto R (2006). Model Pemberdayaan Masyarakat Bidang Kesehatan, Studi Program Desa Siaga Community Empowerment Model in Health Sector, Study on Village Preparadness Program. Jurnal Kesehatan Masyarakat Nasional, 7(36): 186-192.

Tarwoto and wartonah (2011) Kebutuhan Dasar Manusia Dan Proses Keperawatan. Jakarta: Salemba Medika.

Tauso SA, Azizah R (2013). Hubungan Sanitasi Dasar Rumah dan Perilaku Ibu Rumah Tangga dengan Kejadian Diare pada Balita di Desa Bena Nusa Tenggara Timur. Jurnal Kesehatan Lingkungan, 7(1): 1-6.

UNICEF (2010) Penuntun Hidup Sehat. Jakarta: Pusat Promosi KesehatanKemenkes RI.

WHO/UNICEF (2017). Safely managed drinking water - thematic report on drinking water 2017: 1-12. doi: 9789241565424.

Widoyono (2011) Penyakit Kronis : Epidemiologi, penularan, pencegahan dan pemberantasannya. Jakarta: Penerbit Erlangga.

Woldu W, Bitew BD, Gizaw Z (2016). Socioeconomic factors associated with diarrheal diseases among under-five children of the nomadic population in northeast Ethiopia. Tropical Medicine and Health. Tropical Medicine and Health, 44(1): 7-14. doi: 10.1186/s41182-016-0040-7. 